This item was submitted to Loughborough's Research Repository by the author.

Items in Figshare are protected by copyright, with all rights reserved, unless otherwise indicated.

\title{
The effect of pore size and porosity on mechanical properties and biological response of porous titanium scaffolds
}

PLEASE CITE THE PUBLISHED VERSION

http://doi.org/10.1016/j.msec.2017.03.249

\section{PUBLISHER}

(C) Elsevier

VERSION

AM (Accepted Manuscript)

\section{PUBLISHER STATEMENT}

This work is made available according to the conditions of the Creative Commons Attribution-NonCommercialNoDerivatives 4.0 International (CC BY-NC-ND 4.0) licence. Full details of this licence are available at: https://creativecommons.org/licenses/by-nc-nd/4.0/

\section{LICENCE}

CC BY-NC-ND 4.0

\section{REPOSITORY RECORD}

Torres-Sanchez, Carmen, Fares R. Almushref, M. Norrito, Keith A. Yendall, Yang Liu, and Paul P. Conway. 2017. "The Effect of Pore Size and Porosity on Mechanical Properties and Biological Response of Porous Titanium Scaffolds". figshare. https://hdl.handle.net/2134/24694. 


\title{
The effect of pore size and porosity on mechanical properties and biological response of porous titanium scaffolds
}

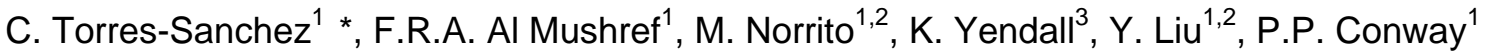 \\ ${ }^{1}$ Wolfson School of Mechanical, Electrical and Manufacturing Engineering, Loughborough University, \\ Leics, LE11 3TU, UK \\ ${ }^{2}$ Centre for Biological Engineering, Loughborough University, Leics, LE11 3TU, UK \\ ${ }^{3}$ Loughborough Materials Characterisation Centre, Loughborough University, Leics, LE11 3TU, UK
}

\begin{abstract}
The effect of pore size and porosity on elastic modulus, strength, cell attachment and cell proliferation was studied for Ti porous scaffolds manufactured via powder metallurgy and sintering. Porous scaffolds were prepared in two ranges of porosities so that their mechanical properties could mimic those of cortical and trabecular bone respectively. Space-holder engineered pore size distributions were carefully determined to study the impact that small changes in pore size may have on mechanical and biological behaviour. The Young's moduli and compressive strengths were correlated with the relative porosity. Linear, power and exponential regressions were studied to confirm the predictability in the characterisation of the manufactured scaffolds and therefore establish them as a design tool for customisation of devices to suit patients' needs. The correlations were stronger for the linear and the power law regressions and poor for the exponential regressions. The optimal pore microarchitecture (i.e. pore size and porosity) for scaffolds to be used in bone grafting for cortical bone was set to $<212 \mu \mathrm{m}$ with volumetric porosity values of $27-37 \%$, and for trabecular tissues to $300-500 \mu \mathrm{m}$ with volumetric porosity values of $54-58 \%$. The pore size range $212-300 \mu \mathrm{m}$ with volumetric porosity values of $38-56 \%$ was reported as the least favourable to cell proliferation in the longitudinal study of 12 days of incubation.
\end{abstract}

\section{Keywords}

Porous Ti, space-holder, Young's modulus, compressive strength, cell behaviour, cell attachment, cell proliferation, cortical bone, trabecular bone

\footnotetext{
* Corresponding author, email: c.torres@lboro.ac.uk, phone: (+44) 01509227518
} 


\section{Introduction}

An optimum balance between mechanical properties and microstructure (i.e. porosity and pore size) must be achieved to ensure successful long-term implantation of load-bearing orthopaedic devices. Replicating the mechanical properties of bone is crucial to avoid: (i) 'stress shielding' that weakens the bone tissue near the implantation region, and (ii) a loosening effect from the lack of cell tissue integration derived from non-porous interfaces [1]. The mechanical properties of human bone tissue depend strongly on anatomical location and bone tissue type (e.g. cortical or trabecular). Elastic modulus and compressive strength for cortical bone have been reported in the ranges of 7-20GPa, more typically 15-19GPa, and 100-250MPa, more typically 180-210MPa, respectively [2-4]. The values for trabecular bone are 1.5-11.2GPa, more typically 2-5GPa, and 11-24MPa, respectively [5-8]. Bone ingrowth requires that the bone graft microstructure is osteoconductive (i.e. it guides the bone ingrowth by providing the cells with a structure/scaffold that promotes cell adhesion and proliferation) and leads to osseointegration of the implant (i.e. the sequential cell differentiation and maturation to create cells within the scaffold) [9]. A vast body of literature has been published reporting optimum pore size range to support growth of cells in regenerative applications. For load-bearing bone grafting applications the pore size range has been established at 50-500 $\mu \mathrm{m}$ [10]. Some authors report that pores larger than $300 \mu \mathrm{m}$ will promote vascularisation [11-13], with cells spanning directly across pores smaller than $150 \mu \mathrm{m}$ and occupying pores larger than $200 \mu \mathrm{m}$ [14]. An optimum size cannot be concluded from the results as this value seems highly dependent on the conditions of the study (e.g. 25 and $200 \mu \mathrm{m}$ had the most positive effect in a range $25-500 \mu \mathrm{m}$ [15], 325 $\mu \mathrm{m}$ when studying $85-$ $325 \mu \mathrm{m}[16], 400 \mu \mathrm{m}$ was preferred when the range studied was $75-900 \mu \mathrm{m}$ [17] and $600 \mu \mathrm{m}$ in a $300-1000 \mu \mathrm{m}$ range [12]).

Titanium is broadly used as a material for orthopaedic devices due to its good corrosion resistance and biocompatibility when implanted. Matching mechanical properties of the $\mathrm{Ti}$ implant to those of bone involves lowering the stiffness of the material almost an order of magnitude (i.e. from $\sim 110 \mathrm{GPa}$ to $\sim 20 \mathrm{GPa}$ [18]). The stiffness of solid Ti can be lowered by introducing a porous structure which is also favourable for osteoconductivity and osseointegration. Techniques such as foaming, replica, rapid prototyping or sintering with space holders have been reported in literature [18-20]. The latter presents advantages that makes it a preferred method for the fabrication of controlled porosity scaffolds. These are easiness in handling Ti raw material, which is highly oxygen-reactive, lower-than-melting temperatures employed in its processing and a fine control on volumetric porosity that resembles that of natural structures such as bone, preferred in bioengineering substrates 
and without straight edges [21]. Shape holder materials such as ammonium hydrogen carbonate, urea, sodium fluoride and chloride, saccharose and PMMA have been used in the manufacture of porous materials to control porosity and pore size [20, 22-24]. Therefore the strength-to-weight ratio can be optimised to match the mechanical properties of bone and these cavities engineered to promote cell proliferation, which results in anchoring of the bone graft in place to minimise loosening in the mid- and long-term.

Once the mechanical properties of host tissue-implanted substrate have been matched, it has been demonstrated that subtle changes in pore size may have significant effects on cell adhesion and proliferation [16]. In this study the optimal pore microarchitecture (i.e. pore size and porosity) for scaffolds to be used in bone grafting for cortical and trabecular tissues is investigated. Porous scaffolds were manufactured in two ranges of porosities so that their mechanical properties could mimic those of cortical and trabecular bone. The mechanical properties (i.e. Young's modulus and compressive strength) were correlated to the relative porosity and regressions then established in a novel attempt to characterise the pore size distribution with existing porous models. Pore size ranges were engineered and studied for how they affect initial cell attachment and subsequent cell proliferation in a longitudinal study to 12 days.

\section{Materials and Methods}

\subsection{Materials}

Commercially available elemental Ti powder (Alfa Aesar, MA, $99.5 \%$ purity, $\leq 45 \mu m$, 325 mesh) was used as the main matrix constituent and Ammonium carbonate $\left(\mathrm{NH}_{4} \mathrm{HCO}_{3}\right)$ (Fisher, 99\% purity) was the space holder.

\subsection{Porous scaffolds preparation}

Ammonium carbonate particles were sieved (Retsch sieve shaker AS 400 control, Germany) to four particle ranges as follows: $45-106 \mu \mathrm{m}$ (referred as 'range 1' thereafter), 106-212 $\mu \mathrm{m}$ (range 2), 212-300 $\mu \mathrm{m}$ (range 3) and 300-500 $\mu \mathrm{m}$ (range 4). The Ti powder was mixed with the space holder. Given the particle size range of the ammonium carbonate, the powder to space holder volume ratio used was adjusted in order to contain two porosity ratios (nominally $55 \%$ and $70 \%$ ). In this way porosity and pore size could be controlled independently. Ti specimens without space holder were also fabricated as control (i.e. nonporous, sintered samples). The green bodies were fabricated by uniaxially cold compacting (Atlas Autotouch Press 40, Specac UK) the Ti/space holder powder mixture at a pressure of $250 \mathrm{MPa}$ into cylindrical green compacts of diameter $14 \mathrm{~mm}$ and height $8 \mathrm{~mm}$. These were 
subjected to a calcination process at $100^{\circ} \mathrm{C}$ dwelling for $10 \mathrm{hr}$ to sublimate the space holders that left voids behind. The sintering process followed in a furnace (Lenton Thermal Designs, UK) equipped with an EcoCube diaphragm pump (Pfeiffer, UK) that achieved a high vacuum (i.e. $<2 \cdot 10^{-5} \mathrm{mbar}$ ). The specimens were heated at a rate of $5^{\circ} \mathrm{C} / \mathrm{min}$ to $1200^{\circ} \mathrm{C}$, allowed to dwell for $12 \mathrm{hr}$ and then cooled down to room temperature at the same rate. The samples were wet ground and polished using an incremental regime from 240- to 1200-grit silicon carbide cloth at $10 \mathrm{~min}$ interval each and finally air dried.

\subsection{Characterisation of the sintered porous scaffolds}

The density of the porous scaffolds $\left(\rho^{*}\right)$, relative density $\left(\rho^{*} / \rho_{s}\right)$, total porosity $(P, \%$ ol) and open porosity $\left(\mathrm{P}_{\mathrm{o}}\right)$ were calculated from the mass-to-volume ratio, the ratio between the density of the porous scaffold versus the density of the sintered, non-porous scaffold, the (1$\left.\rho^{*} / \rho_{\mathrm{s}}\right)$ relationship and the pore volume to total volume ratio, respectively. Pore volume was measured using the Archimedes' method in which the volume displaced by the scaffold corresponded to the matrix volume, and therefore, the closed porosity. Slices of the samples (1.5mm thickness, Buehler Low-Speed saw with oil as a lubricant and without further polishing) were photographed (Nikon D4, 1.6s exposure time, ISO-100, 60mm focal length, f3.8 aperture) and subjected to image analysis (ImageJ, NIH, USA). Pore dimensions were measured from the micrographs obtained using a Nikon Optiphot microscope (Nikon, Japan) with a GXCAM 5 camera (GXOptical, UK), using GXCapture software (GTVision, UK). A constituents and contamination analysis was performed using an Energy Dispersive X-ray Spectrometer (SEM, Hitachi TM3030, Japan / Oxford Instruments Swift ED3000 Silicon drift detector (SDD), UK) which analysed the surface of the scaffolds. Mechanical properties of the scaffolds were obtained under compressive conditions at room temperature using a 3369 Instron bench top universal testing machine (Instron, UK). Samples were loaded at a constant speed of $1 \mathrm{~mm} / \mathrm{min}$. The compressive elastic modulus (i.e. Young's modulus) was obtained from the gradient of the elastic region and the compressive strength from the 'yield point' at which densification or microfracture commenced.

\subsection{In vitro studies}

\subsubsection{Preparation of the scaffolds and cell culture}

Slices of the scaffolds of nominal porosity $55 \%(A)$ and $70 \%(B)$ in the pore ranges 1-4 (i.e. $A 1, A 2, A 3, A 4$ and B1, B2, B3, B4) were cleaned, informed by the cleaning protocol reported in [25], to remove unwanted oil impurities and the outmost oxide layer. Specimens were first stirred in soapy hot water (2hr), soaked in bleach (2hr) and then oven treated 
$\left(200^{\circ} \mathrm{C}\right.$ for $1 \mathrm{hr}$ on each side) to remove contamination of a carbon nature. They were then ultrasonically cleaned while immersed in acetone for $1.5 \mathrm{hr}$ and finally stored in 2-isopropanol at $4^{\circ} \mathrm{C}$ for until further use. Prior to biological tests the samples were sterilized by autoclaving at $121^{\circ} \mathrm{C}$ for $1 \mathrm{hr}$ and thoroughly rinsed in deionised sterile water.

Culture media was prepared using MEM enriched with $10 \%$ fetal bovine serum (FBS), $1 \%$ Lglutamine, $1 \%$ non-essential amminoacids (Sigma, UK). Human bone osteosarcoma cell line 143B (ECACC no. 91112502) were defrosted and seeded in standard flasks. They were incubated in a $5 \% \mathrm{CO}_{2}$ atmosphere at $37^{\circ} \mathrm{C}$ in an incubator (Thermo Scientific Heracell ${ }^{\mathrm{TM}}$ 150 , UK). Media was changed every 3 days for the entire duration of the experiment.

\subsubsection{Cellular viability and proliferation}

Specimens A1-4 and B1-4 were placed in 24 low-adherence multiwell plates (Corning Costar $\left.{ }^{\circledR}, \mathrm{UK}\right)$ and soaked in $1.5 \mathrm{ml}$ of the culture media for $2 \mathrm{hr}$ until cell seeding. Non-porous slices were used as control blanks. Cells $(5,000$ cells per well) were seeded onto each of the specimens and the control wells. Cells were let to attach for $2 \mathrm{hr}$ and culture wells were refilled with $2 \mathrm{ml}$ of enriched medium. Cell viability and morphology were tested at $3,7,12$ days of incubation.

\subsubsection{Presto Blue assay for cell viability}

The Presto blue viability assay contains a cell permeable resazurin-based solution that functions as a cell viability indicator by using the reducing power of living cells to quantitatively measure their proliferation. This analogue allowed the quantification of initial attachment, spreading and proliferation rate of the 143B osteoblasts after 1, 3, 7 and 12 days of culture. At each time point an amount of $500 \mu \mathrm{L}$ of culture medium containing $50 \mu \mathrm{L}$ of the Presto blue reagent (Thermo Fisher Scientific, UK) was added into each well according to the manufacturer's protocol. The plate then was incubated at $37^{\circ} \mathrm{C}$ in humidified atmosphere for $90 \mathrm{~min}$. Fluorescence was measured using a spectrophotometer (Fluostar $\AA$, Omega, UK) at 560nm ex/590nm em. Fluorescence intensity values were converted and are expressed as the reduction percentage of the Presto blue reagent according to the manufacturer's protocol.

\subsubsection{Toluidine Blue assay for cell staining}

Toluidine blue, a basic thiazine metachromatic dye with high affinity for acid tissue components, was used to stain cell propagation after 12 days. Specimens were soaked with $0.02 \% \mathrm{w} / \mathrm{v}$ of Toluidine Blue in Phosphate Buffer (Sigma-Aldrich, UK) and store for $20 \mathrm{~min}$ at 
room temperature. Samples were then gently washed to remove excess of Toluidine solution and purple-spotted surfaces photographed (Nikon S2500).

\subsubsection{Cell Morphology}

On day 12 specimens were fixed for SEM observation with $4 \%$ glutaraldehyde in $0.1 \mathrm{M}$ cacodylate buffer overnight at $4^{\circ} \mathrm{C}$. Post fixation was performed with $2 \%$ Osmium tetroxide $\left(\mathrm{OsO}_{4}\right)$ for $2 \mathrm{hr}$ at room temperature. Dehydration was achieved by means of $15 \mathrm{~min}$ rinsing stages in increasing ethanol concentration solution $(30 \%, 50 \%, 70 \%, 95 \%$ and $100 \%$ in triplicate). Subsequently samples were soaked in three hexamethyldisilazane solutions (2:1 ethanol 100\% in HMDS, $1: 2$ ethanol 100\% in HMDS and final 100\% HDMS solution) and dried overnight. The specimens were mounted and gold/palladium sputter coated for cell morphology SEM analysis (JEOL/ZEISS JSM 7800F FESEM, Japan).

\subsubsection{Statistical Analysis}

Mechanical properties results are presented as a mean \pm SD. Experiments were performed in triplicate for each pore size range and porosity and at each time point. Statistical analysis for the biological tests was performed using the computing environment $R$ ( $R$ Development Core Team, 2005). Distribution of data was verified using the Shapiro Normality Test and any significant differences in cell viability were detected using the ANOVA Parametric Test and Fisher LSD post-hoc test. Differences at $p<0.05$ were considered statistically significant.

\section{Results}

3.1. Structural and mechanical properties

Chemical analysis on the scaffolds yielded results presented in Table 1. Inspection of the scaffolds surfaces (Figure 1) allowed pore size distributions to be quantified and these are presented in Figure 2.

Table 1: Chemical composition (EDS) results

\begin{tabular}{|l|l|l|l|l|l|}
\hline Element & $\mathrm{Ti}$ & $\mathrm{C}$ & $\mathrm{Al}$ & $\mathrm{Si}$ & $\mathrm{Br}$ \\
\hline$\%$ \%t (SD) & $96.050(1.831)$ & $4.265(0.679)$ & $2.064(0.325)$ & $1.078(0.003)$ & $1.232(0.011)$ \\
\hline
\end{tabular}



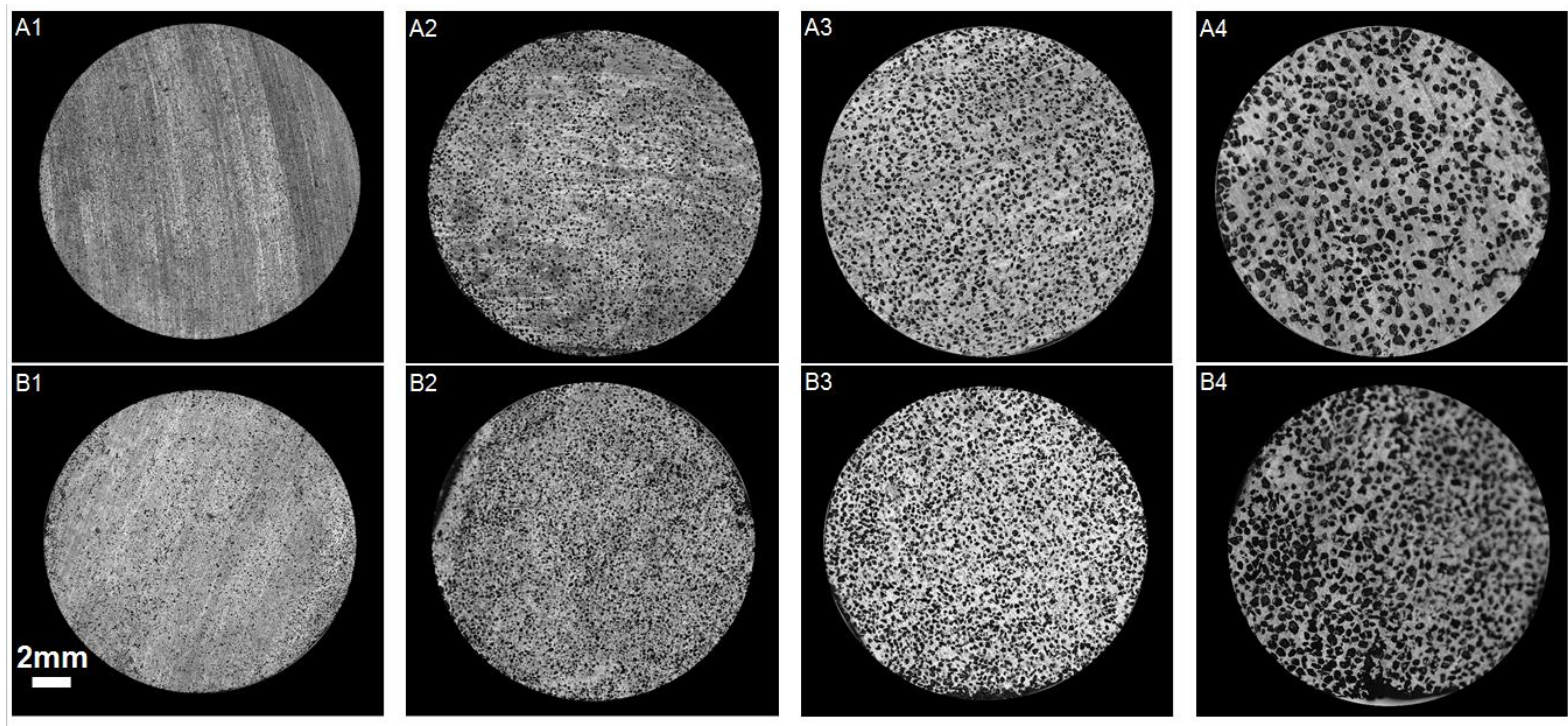

Figure 1: Micrographs from scaffolds with nominal 55\%vol porosity A1-4 (top row) and $70 \%$ vol nominal porosity B1-4 (bottom row) 

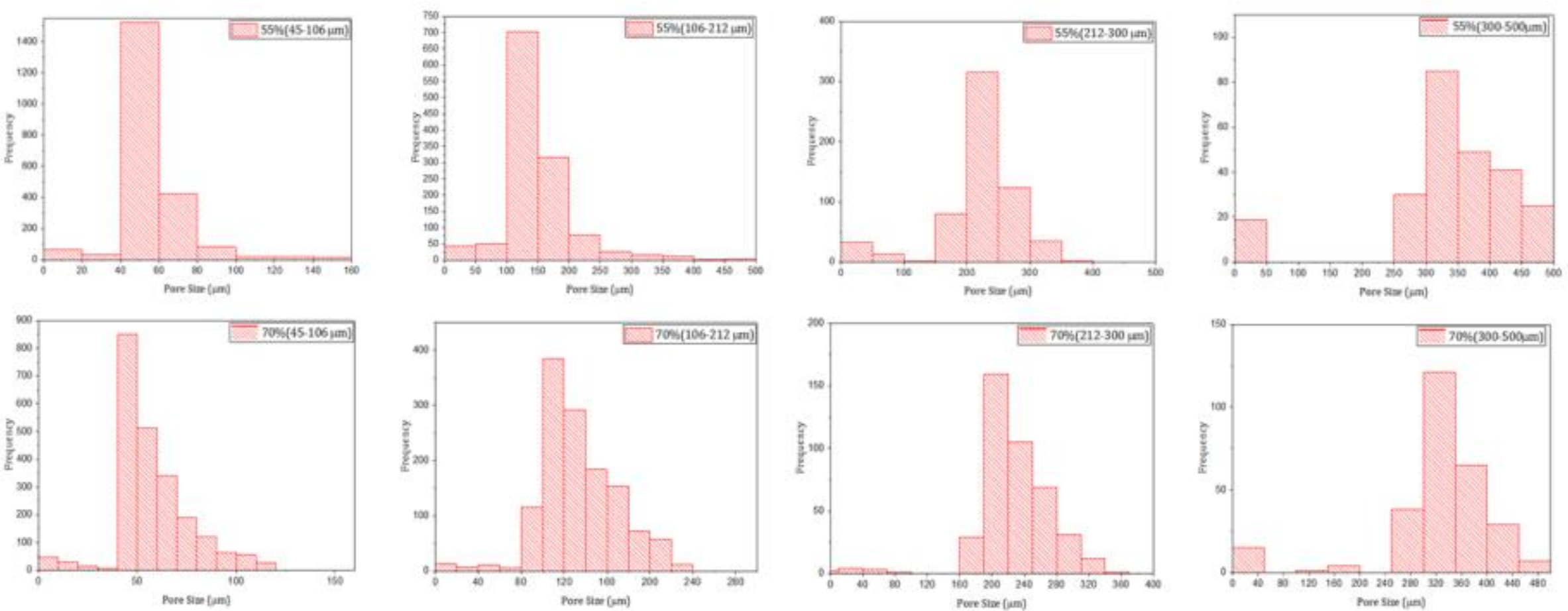

Figure 2: Pore size distribution for the two ranges of porosity: 55\%vol porosity A1-4 (top row) and 70\%vol nominal porosity B1-4 (bottom row) 
The mechanical properties obtained from the tests (i.e. compressive Young's modulus and modulus of elasticity in compression, $\mathrm{E}^{*}$, and compressive strength at the end of the elastic region, $\sigma^{*}$ ) were compiled along with the experimental values of density $\left(\rho^{*}\right)$, total porosity $\left(\%\right.$ vol) $(\mathrm{P})$ and open porosity $(\% \mathrm{vol})\left(\mathrm{P}_{\mathrm{open}}\right)$ (Table 2$)$. Figure 3 shows the relationship between (i) the ratio Young's modulus of the porous sample $\left(E^{*}\right)$ to that of the solid sintered sample $\left(E_{s}\right)$ and (ii) the ratio of the compressive strength of the porous sample $\left(\sigma^{*}\right)$ to that of the sintered samples $\left(\sigma_{\mathrm{s}}\right)$ and the total porosity (vol). The total porosity (in volumetric ratio) and the corresponding open porosity with respect to the density of the porous solid were plotted in Figure 4.

Table 2: Ti porous scaffolds manufactured with different pore size ranges and porosity

\begin{tabular}{|c|c|c|c|c|c|c|}
\hline $\begin{array}{l}\text { Nominal } \\
\text { porosity, } \\
\% \text { vol }\end{array}$ & $\begin{array}{l}\text { Label } \\
\text { (Pore } \\
\text { size, } \mu \mathrm{m})\end{array}$ & $\begin{array}{l}\rho^{*}, \mathrm{~g} / \mathrm{cm}^{3} \\
\text { (SD) }\end{array}$ & $\begin{array}{l}\text { Porosity, } \\
\text { \%vol (SD) }\end{array}$ & $\begin{array}{l}\text { Open } \\
\text { Porosity, } \\
\% \text { ovol } \\
\text { (SD) }\end{array}$ & $\begin{array}{l}\mathrm{E}^{\star}, \mathrm{GPa} \\
\text { (SD) }\end{array}$ & $\begin{array}{l}\sigma^{*}, \mathrm{MPa} \\
\text { (SD) }\end{array}$ \\
\hline $0 \%$ & nil & $\begin{array}{l}4.318 \\
(0.053)\end{array}$ & $\begin{array}{l}\text { Inherent } \\
4.181 \\
(0.001) \\
\end{array}$ & Nil & $\begin{array}{l}42.371 \\
(0.510)\end{array}$ & $\begin{array}{l}460.00 \\
(3.770)\end{array}$ \\
\hline $55 \%$ & $\begin{array}{l}\text { A1 } \\
(45-106) \\
\text { A2 } \\
(106-212) \\
\text { A3 } \\
(212-300) \\
\text { A4 } \\
(300-500)\end{array}$ & $\begin{array}{l}3.086 \\
(0.046) \\
2.750 \\
(0.020) \\
2.824 \\
(0.022) \\
2.696 \\
(0.014) \\
\end{array}$ & $\begin{array}{l}28.534 \\
(1.067) \\
36.305 \\
(0.465) \\
34.593 \\
(0.499) \\
37.563 \\
(0.320) \\
\end{array}$ & $\begin{array}{l}5.889 \\
(0.779) \\
16.686 \\
(0.567) \\
12.295 \\
(1.050) \\
13.160 \\
(0.329) \\
\end{array}$ & $\begin{array}{l}16.862 \\
(0.220) \\
17.406 \\
(0.526) \\
15.493 \\
0.703) \\
16.488 \\
(0.593) \\
\end{array}$ & $\begin{array}{l}268.427 \\
(5.227) \\
248.303 \\
(13.158) \\
235.193 \\
(10.425) \\
166.973 \\
(50.582) \\
\end{array}$ \\
\hline $70 \%$ & $\begin{array}{l}\text { B1 } \\
(45-106) \\
\text { B2 } \\
(106-212) \\
\text { B3 } \\
(212-300) \\
\text { B4 } \\
(300-500)\end{array}$ & $\begin{array}{l}2.563 \\
(0.065) \\
2.092 \\
(0.015) \\
2.109 \\
(0.035) \\
1.926 \\
(0.041) \\
\end{array}$ & $\begin{array}{l}40.638 \\
(1.513) \\
51.557 \\
(0.359) \\
51.150 \\
(0.820) \\
55.386 \\
(0.941)\end{array}$ & $\begin{array}{l}18.856 \\
(2.427) \\
31.658 \\
(1.194) \\
31.181 \\
(1.233) \\
37.088 \\
(1.804)\end{array}$ & $\begin{array}{l}6.185 \\
(0.631) \\
5.653 \\
(0.438) \\
6.579 \\
(0.228) \\
6.168 \\
(0.428) \\
\end{array}$ & $\begin{array}{l}155.263 \\
(2.733) \\
112.910 \\
(16.019) \\
100.657 \\
(32.222) \\
74.443 \\
(17.120)\end{array}$ \\
\hline
\end{tabular}




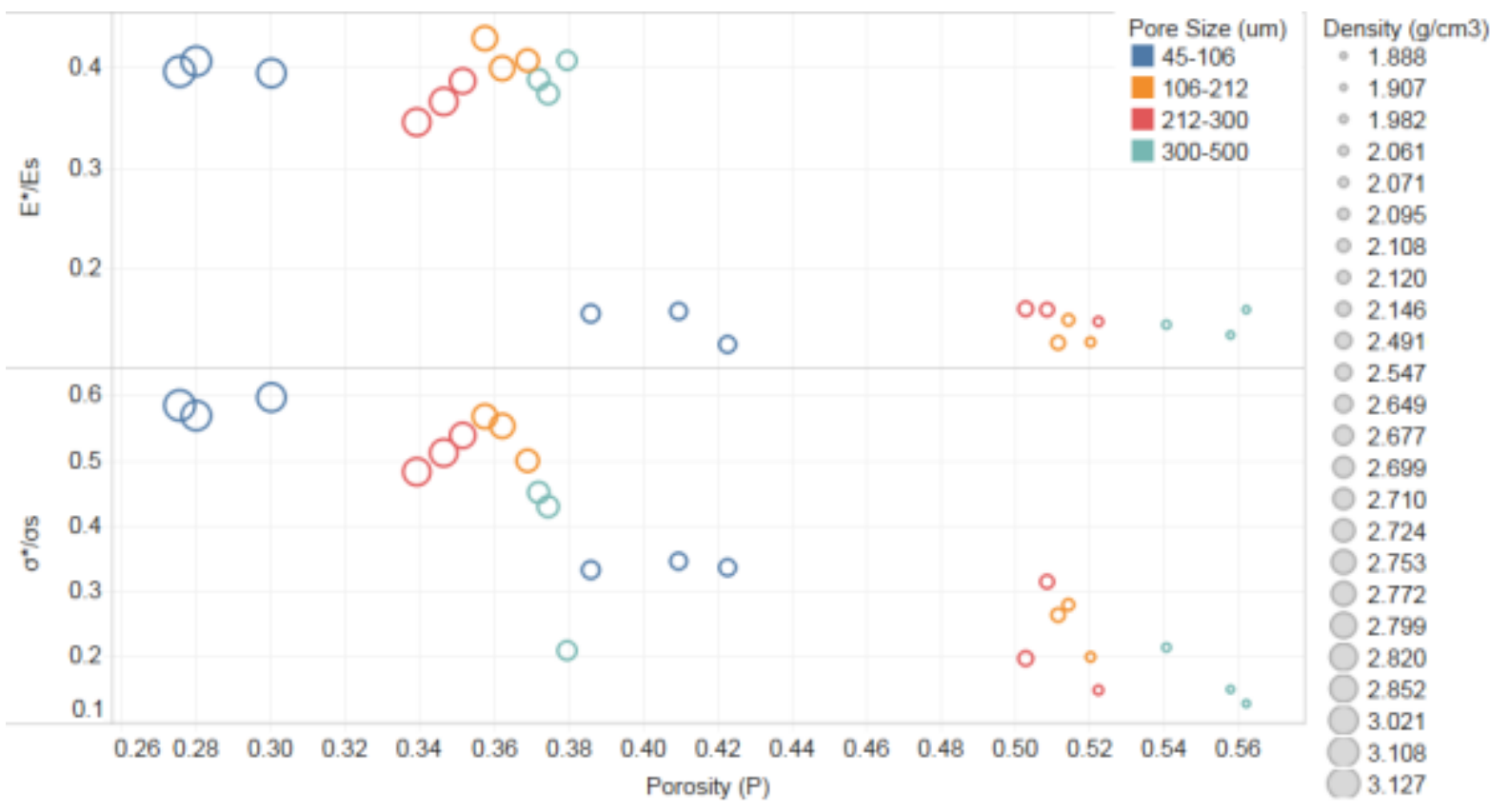

Figure 3: Relative Young's moduli and relative compressive strength versus porosity for the 4 ranges of pore size: (1) 45-106, (2) 106-212, (3) 212-300, (4) 300-500 $\mu \mathrm{m}$. Dot size is proportional to sample density

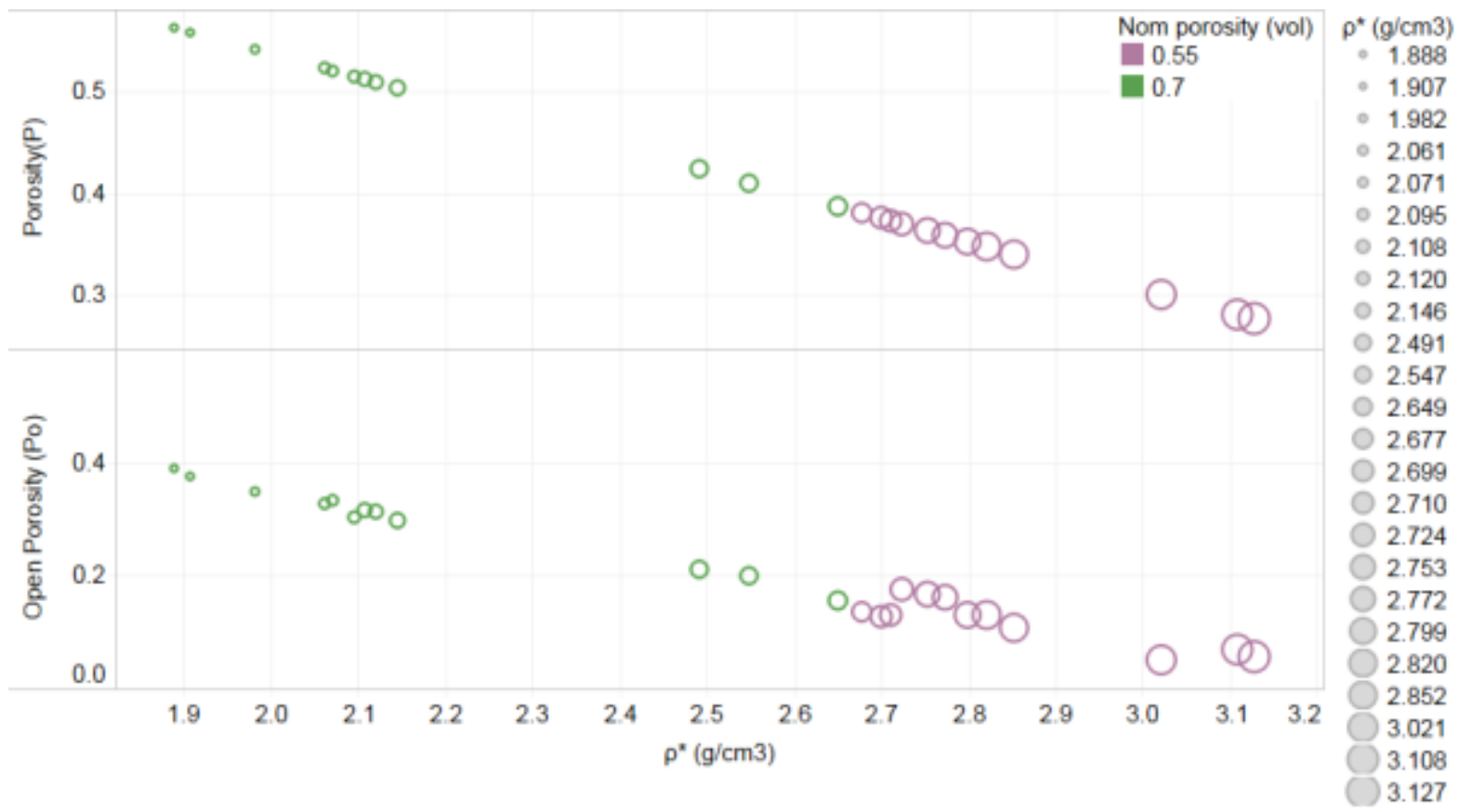

Figure 4: Total porosity and Open porosity in volumetric ratios versus density of the porous solid for the $55 \%$ (A) and $70 \%$ (B) nominal porosity by design. Dot size is proportional to sample density 
Linear, power and exponential regressions were applied to the Young's moduli, compressive strengths and volumetric porosity to confirm predictable characterisation of the scaffolds manufactured. The results are summarised in Table 3.

Table 3: Summary of relationships for relative Young's moduli and compressive strengths

\begin{tabular}{|c|c|c|c|c|}
\hline \multirow{2}{*}{ Linear } & \multicolumn{3}{|c|}{$E^{*}$} & \multirow[t]{2}{*}{$\sigma^{*}$} \\
\hline & Pore size $\mu \mathrm{m}$ & $A^{2}$ & $\mathrm{R}^{2}$ & \\
\hline $\mathrm{M}^{*} / \mathrm{M}_{\mathrm{s}}=1-\mathrm{aP}$ & $45-500$ & 1.719 & 0.562 & \\
\hline [26] $\left(E^{\star}\right)$ & $45-106$ & 2.102 & 0.969 & \\
\hline & $106-212$ & 1.662 & 0.987 & \\
\hline & $212-300$ & 1.708 & 0.847 & \\
\hline & $300-500$ & 1.569 & 0.953 & \\
\hline
\end{tabular}

\begin{tabular}{|c|c|c|c|c|c|c|c|}
\hline Power & & & $\mathrm{u}$ & $\mathrm{R}^{2}$ & & $\mathrm{u}$ & $\mathrm{R}^{2}$ \\
\hline $\begin{array}{l}M^{*} / M s=1-u P^{2 / 3} \\
{[27]\left(E^{\star}\right)}\end{array}$ & $45-500$ & & 1.313 & 0.726 & & & \\
\hline $\begin{array}{l}\mathrm{M}^{*} / \mathrm{Ms}=\mathrm{C}_{1}(1-\mathrm{P})^{\mathrm{n}} \\
{[28,29]\left(\mathrm{E}^{*}\right)} \\
{[30]\left(\mathrm{E}^{*}\right)} \\
\text { [31] (both) }\end{array}$ & $\begin{array}{l}45-500 \\
45-106 \\
106-212 \\
212-300 \\
300-500\end{array}$ & $\begin{array}{l}c_{1} \\
1.049 \\
2.316 \\
2.621 \\
1.256 \\
1.513\end{array}$ & $\begin{array}{l}\mathrm{n} \\
2.665 \\
5.282 \\
4.111 \\
2.914 \\
2.896\end{array}$ & $\begin{array}{l}\mathrm{R}^{2} \\
0.717 \\
0.973 \\
0.989 \\
0.987 \\
0.973\end{array}$ & $\begin{array}{l}\mathrm{c}_{1} \\
1.526 \\
1.465 \\
2.039 \\
1.925 \\
1.079\end{array}$ & $\begin{array}{l}\mathrm{n} \\
2.739 \\
2.785 \\
2.941 \\
3.112 \\
2.401\end{array}$ & $\begin{array}{l}\mathrm{R}^{2} \\
0.803 \\
0.934 \\
0.947 \\
0.828 \\
0.690\end{array}$ \\
\hline
\end{tabular}

\begin{tabular}{|c|c|c|c|c|c|c|c|}
\hline Exponential & & C & $b$ & $R^{2}$ & C & $b$ & $\mathrm{R}^{2}$ \\
\hline $\mathrm{M}^{*} / \mathrm{Ms}=\mathrm{ce}^{-\mathrm{bP}}$ & $45-500$ & 1.746 & 4.754 & 0.726 & 2.524 & 4.832 & 0.795 \\
\hline [32] (both) & $45-106$ & 3.986 & 8.120 & 0.973 & 1.955 & 4.288 & 0.937 \\
\hline [33] $\left(\sigma^{*}\right)$ & $106-212$ & 5.975 & 7.378 & 0.989 & 3.670 & 5.274 & 0.945 \\
\hline & $212-300$ & 2.156 & 5.140 & 0.986 & 3.409 & 5.474 & 0.823 \\
\hline & $300-500$ & 3.028 & 5.476 & 0.976 & 1.906 & 4.526 & 0.688 \\
\hline
\end{tabular}

\begin{tabular}{llllllll} 
Ln $\mathrm{M}^{*}=-$ & & $\mathrm{a}$ & $\mathrm{b}$ & $\mathrm{R}^{2}$ & $\mathrm{a}$ & $\mathrm{b}$ & $\mathrm{R}^{2}$ \\
$\mathrm{bP}_{\text {open }}+\mathrm{a}$ & & & & & & & \\
[34] (both) & $45-500$ & 3.146 & 4.018 & 0.701 & 5.871 & 4.039 & 0.7509 \\
& $45-106$ & 3.235 & 7.386 & 0.951 & 5.803 & 3.913 & 0.921 \\
& $106-212$ & 4.102 & 7.483 & 0.993 & 6.425 & 5.422 & 0.975 \\
& $212-300$ & 3.282 & 4.466 & 0.976 & 6.040 & 4.736 & 0.808 \\
& $300-500$ & 3.326 & 4.048 & 0.966 & 5.522 & 3.380 & 0.695 \\
\hline \hline
\end{tabular}

\begin{tabular}{|c|c|c|}
\hline Other equations & $y$ & $R^{2}$ \\
\hline $\begin{array}{lll}\mathrm{M}^{*} / \mathrm{Ms}= & (1- & 45-500 \\
\mathrm{P})^{2} /(1+\mathrm{P})\end{array}$ & 1.094 & 0.717 \\
\hline
\end{tabular}

[35] $\left(E^{*}\right)$ 


\subsection{Biological properties}

Cell viability results via the Presto blue assay are shown in Figure 5 and the proliferation rates at each time point are listed in Table 4.

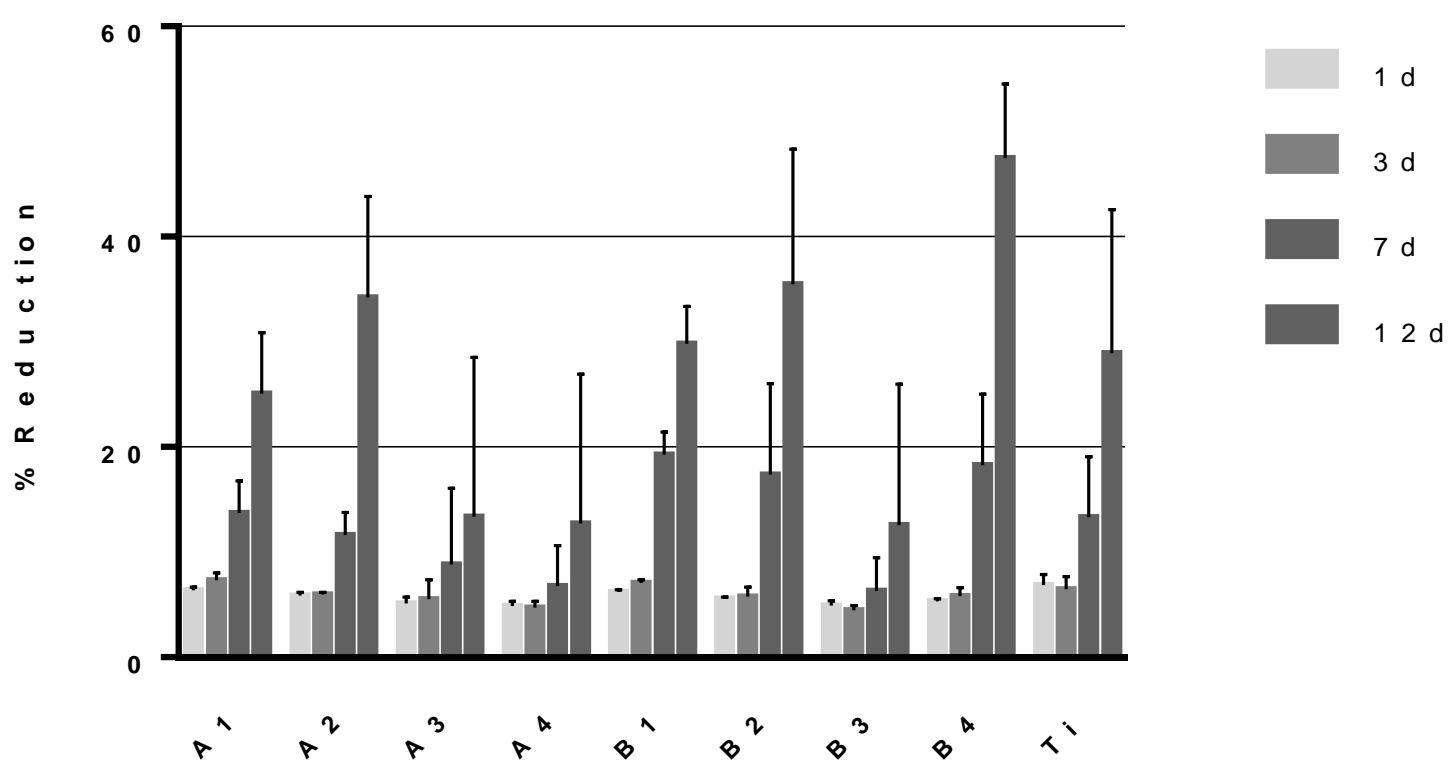

Figure 5: Effect of porosity and pore size on cell viability for scaffolds cultured for 1, 3, 7, 12 days

Table 4: Proliferation rate of 143B osteoblasts on titanium porous and non-porous scaffolds. The rate was measured normalizing the intensity values obtained on days 3,7 and 12 to the first day of culture ('i//io').

\begin{tabular}{lrrr}
\multicolumn{1}{c}{ Sample } & Day 3 & Day 7 & Day 12 \\
A1 & 1.146 & 2.144 & 3.243 \\
A2 & 1.014 & 1.975 & 5.814 \\
A3 & 1.079 & 1.731 & 2.620 \\
A4 & 0.972 & 1.386 & 2.602 \\
B1 & 1.137 & 3.098 & 4.797 \\
B2 & 1.036 & 3.128 & 6.385 \\
B3 & 0.907 & 1.286 & 2.559 \\
B4 & 1.099 & 3.436 & 8.938 \\
\hline Non-porous Ti & 0.945 & 1.938 & 4.208 \\
\hline
\end{tabular}

These results show that after a slow start (i.e. day 3 data) the cells reached substantial growth towards the end of the study (i.e. day 12 data). Cell viability via \%reduction of the fluorescence intensity was also studied at each time point independently (Figure 6) and at each condition of porosity and pore size range (Figure 7). 
a)

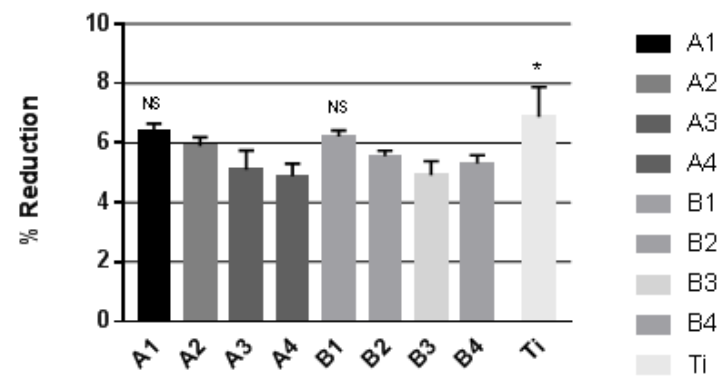

c)

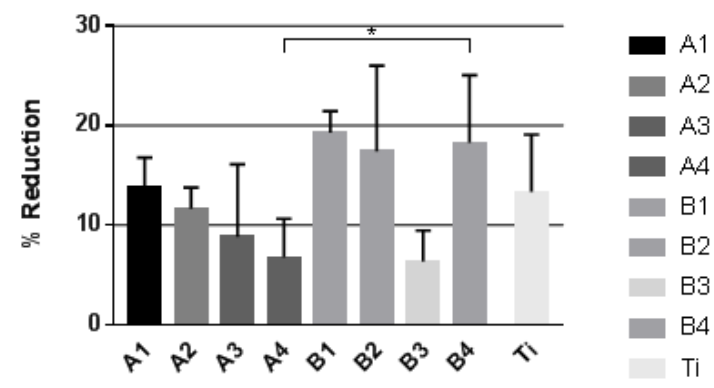

b)

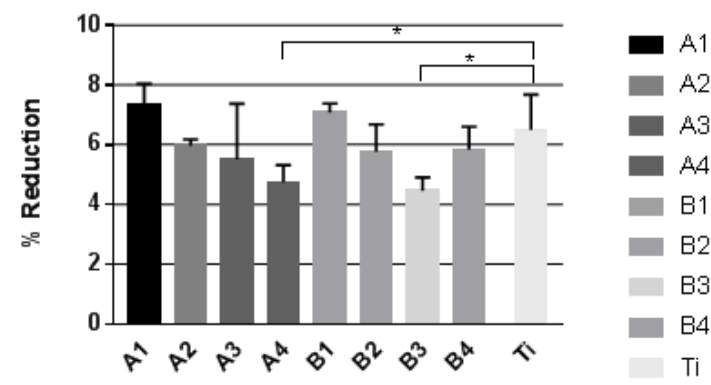

d)

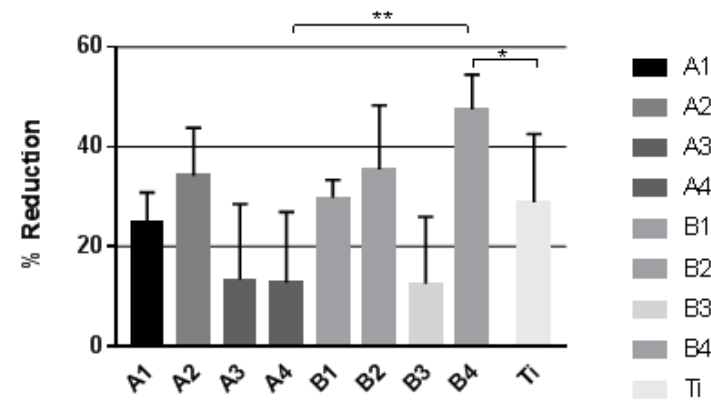

Figure 6: Viability of cells on the porous and non-porous scaffolds at (a) 1 day, (b) 3 days, (c) 7 days and $(d) 12$ days of incubation. $\left(^{*}\right)$ denotes $p<0.05$ and $\left({ }^{* *}\right) p<0.005$

a)

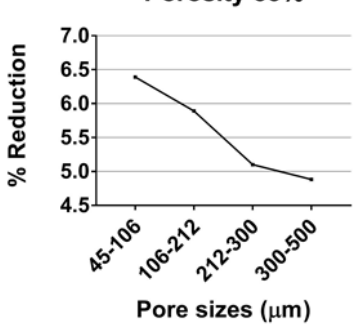

Porosity $\mathbf{7 0} \%$

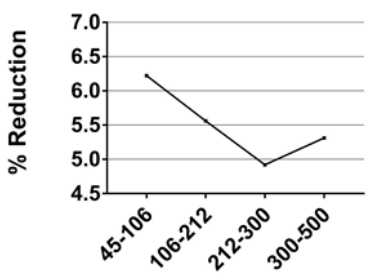

Pore sizes $(\mu \mathrm{m})$ b)

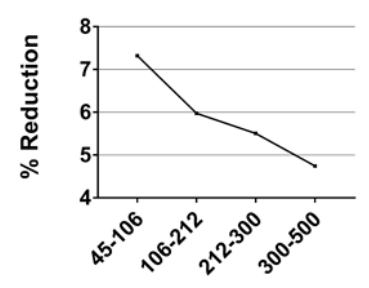

Pore sizes $(\mu \mathrm{m})$

Porosity $70 \%$

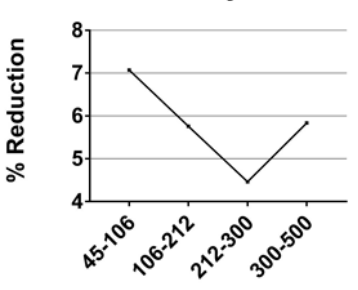

Pore sizes $(\mu \mathrm{m})$ c)

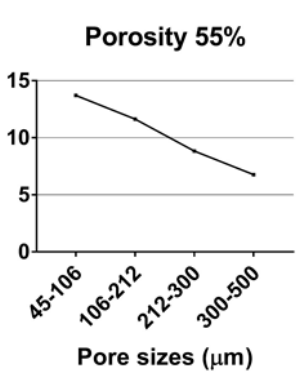

Porosity $70 \%$

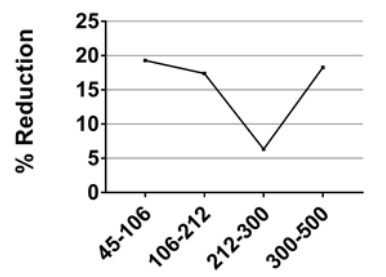

Pore sizes $(\mu \mathrm{m})$ d) Porosity $55 \%$

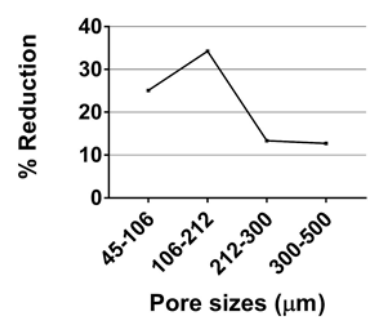

Porosity $\mathbf{7 0 \%}$

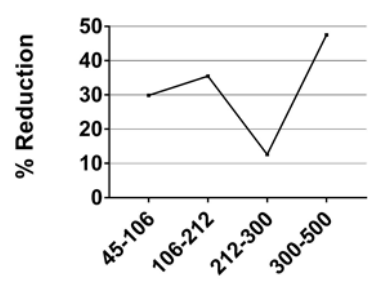

Pore sizes $(\mu \mathrm{m})$

Figure 7: Viability of cells on the porous and non-porous scaffolds per nominal porosity and pore size range at (a) 1 day, (b) 3 days, (c) 7 days and (d) 12 days of incubation

Toluidine staining on day 12 of the study qualitatively evaluated cell growth on the scaffolds (Figure 8). Blue spots indicated the presence of metabolic reactive cells on the surfaces of 
lower and higher porosity scaffolds with small pore ranges (A1, A2, B1 and B2) and higher porosity with largest pore size range (B4). When compared to other samples B4 group specimens presented a non-homogeneous, patchy, distribution of blue hue spots. SEM images were obtained on incubation days 3,7 and 12. The scaffolds showed a low population of cells in day 3 , but to the contrary, cells formed well and spread in days 7 and 12 , covering the surfaces, filling pores and in some cases spanning across gaps.

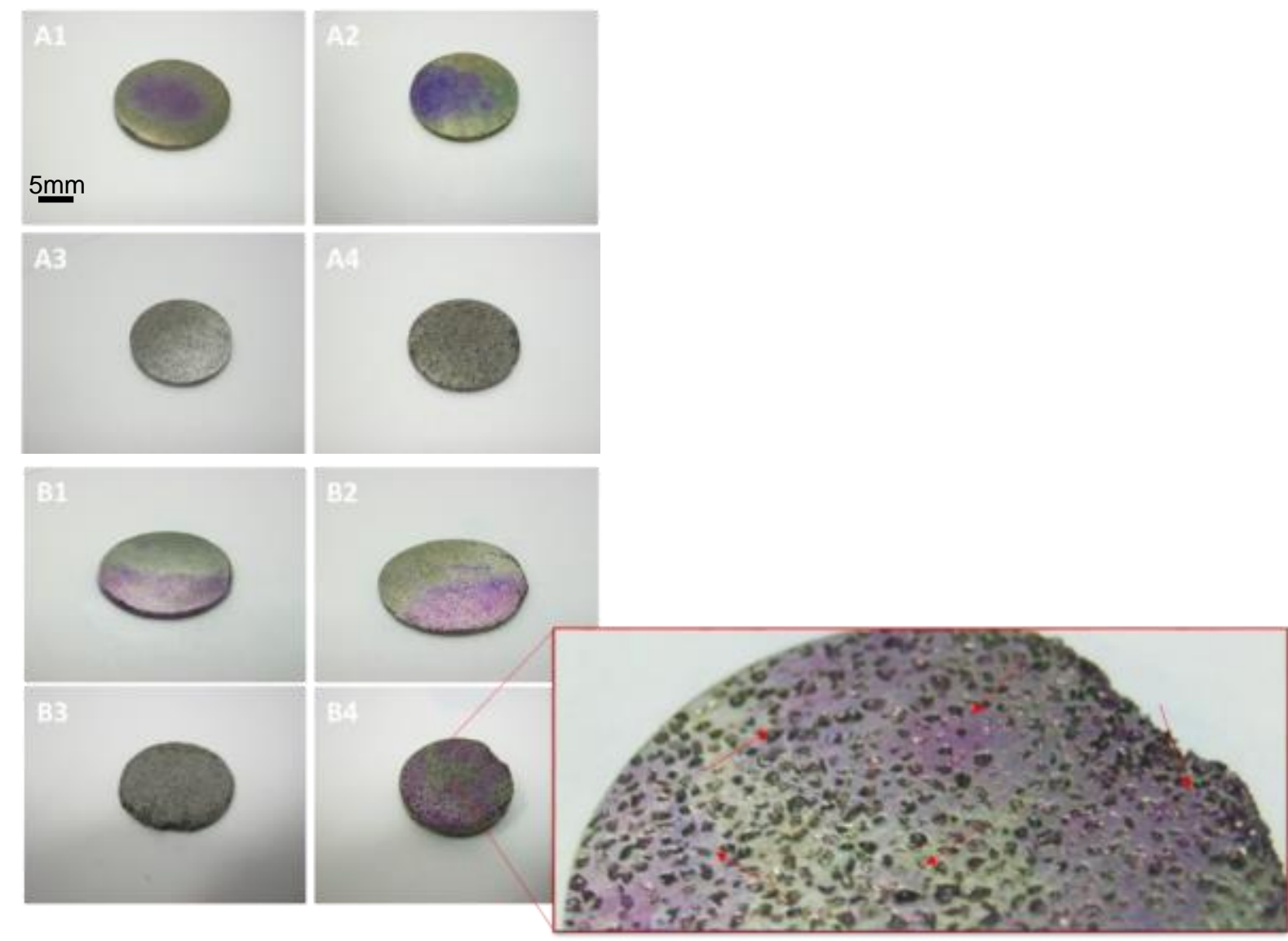

Figure 8: Qualitative cell growth progression evaluated with Toluidine blue dye. Specimens were cultured for 12 days

\section{Discussion}

The 55\% nominal porosity scaffolds (A1-4) presented a final total porosity in the range 27$37 \%$ vol, with $5-13.5 \%$ being open volumetric porosity, which is aligned to that of cortical bone. The results for the $70 \%$ nominal porosity set (B1-4) were $38-56 \%$ and $15-39 \%$, respectively, which is much lower than trabecular bone ( 80\%). Packing effects and densification due to particles $\leq 45 \mu \mathrm{m}$ may explain this reduced level with respect to the 
intended value. Inspection of the pore size populations (Figure 2) indicated that there was no shrinkage of the pores after calcination of the space holder.

The mechanical properties results from the A1-4 group reported a Young's modulus in the range 15.46-18.12GPa, which corresponds to the elastic modulus of cortical bone, a compressive strength at yield point range $222-274 \mathrm{MPa}$, also comparable to that of cortical tissue. The values produced for the B1-4 set were 5.29-6.72GPa for the Young's modulus, 67-159MPa for the compressive strength. These values correlated well in terms of modulus of elasticity but were $84 \%$ larger for strength.

The Young's modulus for the A1-4 range of porosity was in agreement with other titanium porous sintered scaffolds reported [36] and improved upon other Ti powder metallurgical specimens [37] obtained through the same manufacturing route. The values obtained for the B1-4 range of porosity can also be found in other Ti porous scaffolds with similar porosity and pore size features manufactured via 3D printing [38], indicating the material properties become independent from the manufacturing method once a certain level of porosity is surpassed. The values obtained for compressive strength were also in agreement with other studies [36]. We obtained similar values of strength to [39] but a larger Young's modulus, and a similar Young's modulus to [40] but a larger value for the strength, confirming the suitability of the compaction and sintering method without oxidation (Table 1).

The space-holder volumetric content remained constant while the pore size ranges varied. This allowed the study of pore size independently from porosity. Relative values of Young's modulus and compressive strength were calculated as the ratio to the corresponding value of the sintered scaffolds with nil porosity (i.e. $E^{*} / E_{s}$ or $\sigma^{*} / \sigma_{s}$ ) to achieve a realistic correspondence, as already mentioned in other studies [36].

A linear correlation between the relative Young's modulus ( $\left.E^{*} / E s\right)$ and the volume porosity (P) was applied to the results. Hasselman and Fulrath [26] proposed the experimental fitting parameter $(\mathrm{a})$ was dependent on the Poisson's ratio $\left(\mathrm{v}_{0}\right)$ of the matrix material through $a=3\left(9+5 v_{0}\right)\left(1-v_{0}\right) /\left[2\left(7-5 v_{0}\right)\right]$. As per the calculation $a=2$ in this study since the Poisson's ratio for $\mathrm{Ti}$ is 0.33 . The empirical values for a are listed in Table 3 and spanned 1.57 to 2.1. The best correlation corresponded to the lowest range of porosity, as expected, due to the model's limitations.

Power correlations between the relative Young's modulus and the volumetric porosity rendered good fitting results for the Martin and Haynes model [27] since they observed (u) ranges from 1.27 to 1.55 for cold pressed and sintered porous materials with a porosity $<60 \%$ and the result obtained in this study was 1.313. Bal'shin [28] defined a similar correlation for 
the tensile strength and Young's modulus, and (n) ranged from 3 to 6 for sintered metals depending on time and sintering duration being 3 if under optimum process conditions for the Young's modulus. Strength results cannot be compared with this study. Our results mildly matched those values with 2.7 for the entire range and 2.9-5.2 for the separate pore ranges. Wagh et al [29] established a range from 2.02 to 5.48 for the Young's modulus based on experimental data, including hot pressed and sintered powders which laid in the upper limit of the range. Maitra and Phani [30] set the range from 3.1 to 3.9 for sintered powder compacts porosity values that include those in this study $(<65 \%)$ and established 2 for higher degrees of organisation and 4 for the random distribution and orientation of pores. Our values fell comfortably into these ranges. Gibson and Ashby [31] also proposed power laws for $(n)$ values that depend on microarchitecture of the pore structure, with values of 2 for open porosity and 3 for transverse or closed pores. The results from this study reported a mixed microarchitecture based on the resultant fitting parameters. The results obtained did not offer a good match in exponential correlations. For the Young's modulus Knudsen [32] proposed $b=3.95$ (4.75 in this study) and for the compressive strength Duckworth/Rhyshkewitch [33] $b=7$ (4.83 in this study). In both cases the porosity range spanned to 40 and $50 \%$ respectively. This mismatch can be explained by the manufacturing method, which is not stated in either of the studies. On the contrary, studies on sintered porous materials with porosities ranging 3-50\% [34] that relate open porosity to both Young's modulus and compressive strength relied on fitting values of 4.022 , which our results were in agreement with $(4.018,4.039)$ with better $R^{2}$ values than the reported study. Finally the experimental results showed good agreement with Mondal et al's metal foam model [35], which is applicable to most of this study's entire range (i.e. $30 \%<\mathrm{P}<80 \%$ ) and rendered an experimental value for $\mathrm{y}=1.094$ when the theoretical value was $\mathrm{y}=2-3 \mathrm{v}_{0}=1$ with Ti Poisson's ratio 0.33 . Therefore, it can be concluded that the power and linear regressions best predicted the mechanical properties of the porous scaffolds when pore size and/or porosity are varied, and they can be used now as a design tool for the customisation of mechanical properties to match patient's needs.

The effect of pore size and porosity on osteosarcoma osteoblasts MB143B proliferation on the Ti scaffolds presented no significant differences until day 3 , as confirmed by the low proliferation rates (Figure 5 and Table 4), which suggests the number of cells remained constant in early days. SEM images confirmed a low count in cell numbers and their compact configuration, with little filopodia and an isolated status (Figure 9a-c). Beyond day 3 however the growth became substantial, confirming the scaffolds viability and noncytotoxicity nature (Figure 9d-i). The fluorescence signal, which correlates with the number of viable cells, increased. 

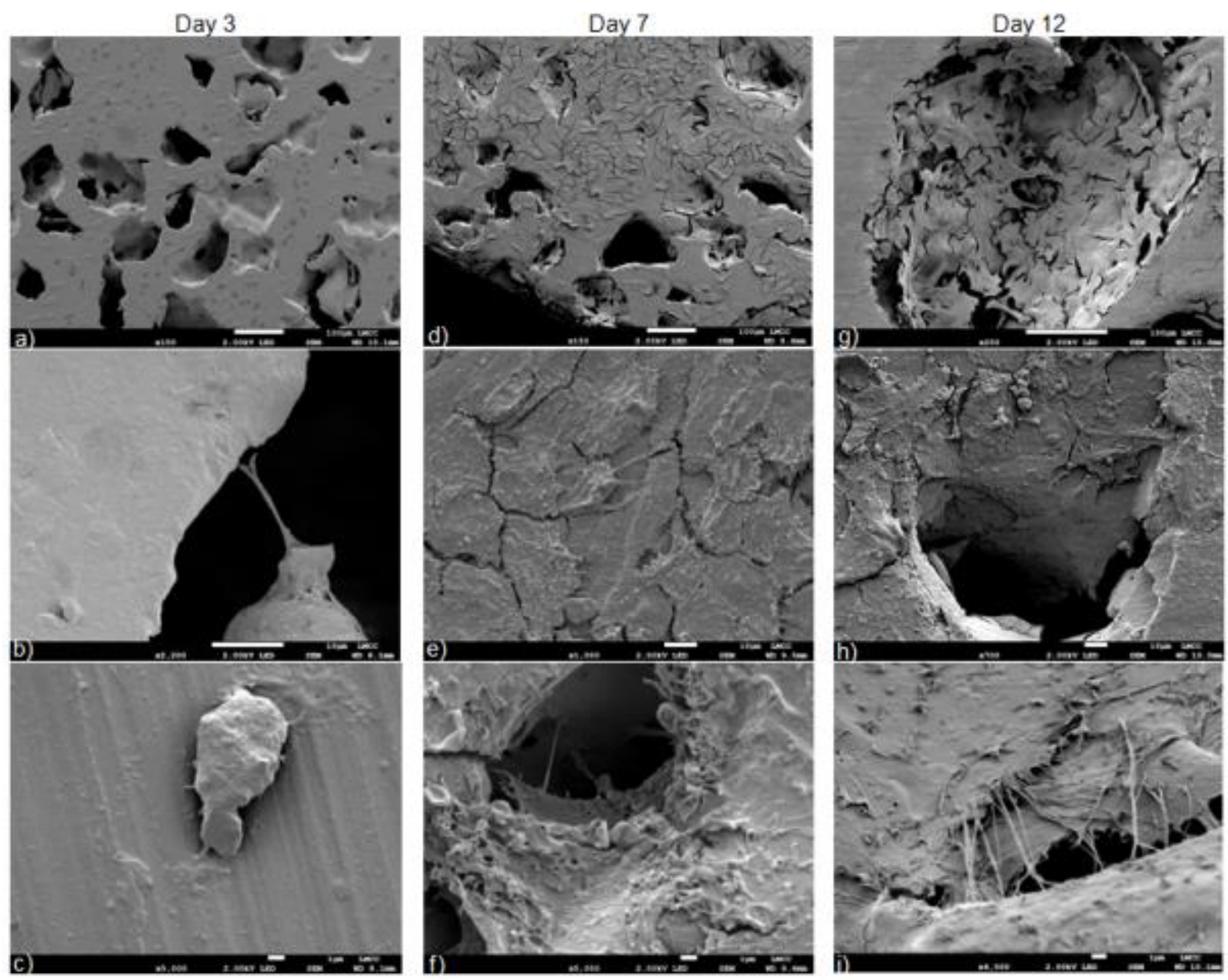

Figure 9: Cell spreading images at incubation days 3, 7 and 12. Day 3: (a) low cell density observed on B2, (b) cell spanning across a pore on A3 and (c) isolated cell with little filopodia on A4. Day 7: (d) cells colonising and attaching onto the surfaces of scaffold A2 and spanning across small pores, (e) surface on A1 reaching confluence, $(f)$ pore bridging on $A 2$ pores $(106<x<212 \mu \mathrm{m})$. Day 12: $(\mathrm{g})$ ingrowth into the pore volume on $A 4,(\mathrm{~h})$ absence of pore bridging on B3 $(212<x<300 \mu \mathrm{m})$, (i) pore bridging on heavy infold growth on B4 $(300<x<500 \mu \mathrm{m})$. Scale bars: (a), (d), (g) $100 \mu \mathrm{m}$; (b), (e), (h) $10 \mu \mathrm{m}$; (c), (f), (j) $1 \mu \mathrm{m}$

It is generally understood that pore sizes and porosity strongly affect the total surface area in the microstructure and in this study these had an influence on cell attachment. Scaffolds of pore range 45-106 $\mu \mathrm{m}$ (groups A1, B1) accomplished larger growth rates in the time points 1 and 3 days when compared to scaffolds with larger pore ranges (A2-4, B2-4) (Figure 6a and b). They presented a statistically significant advantage for cell viability, which indicates scaffold retention of cells. This effect was independent of porosity (Figure $7 a$ and b). In day 1 statistical difference disappears when comparing the rest of the samples to the control (Figure 6a). No significant difference was observed in A1 and B1 compared to the control until day 3. A non-linear correlation between pore size and cell attachment was particularly obvious in the higher porosity ranges. Therefore, it was concluded that small pores that offer 
a large surface area are preferred for the attachment stage (i.e. in the early days). This is in agreement with other researchers: it has been hypothesised that the specific surface area determines a certain ligand density that affects the integrin-binding after initial seeding [16]. However, when cell proliferation was dominant (days 7 and 12) the scaffolds with the smallest pore ranges (A1, B1) performed worse than those of slightly larger pore size (A2, B2) (Figure 7c and d, Table 4 and supplementary material). At those time points larger pore size ranges (A2, B2 and B4) presented also the largest growth rate, which confirms that large pore size supports cell growth (Figure $6 c$ and d), in particular in the most porous set of samples (B4) (Figure 7c and d). This is because there was a geometrical correlation between large pore sizes and less surface area available for the cells to attach to. A similar effect has been observed in other studies in which porous scaffolds of $400 \mu \mathrm{m}$ presented enhanced levels of cell attachment for larger levels of porosity [17]. Scaffolds of pore size 212-300 $\mu \mathrm{m}$ (A3, B3) did not appear to promote cell growth beyond day 7 , and in particular B3 yielded the worst performing results from the entire set (Figure 7, bottom row). We hypothesised that high porosity levels and a pore range of 212-300 $\mu \mathrm{m}$ (B3) combines the least favourable conditions for cell growth when the seeding density is low, i.e. large pores across which the cells have to span and high porosity that scatters the cells, thus interfering with their static growth and potentially halting all proliferation (Figure 7c, 55\%). This result agrees with other studies carried out to 7 days of incubation [16]. Contrary to our results, other studies have shown that $100 \mu \mathrm{m}$ is least and $200 \mu \mathrm{m}$ is most favourable to cell proliferation on porous Ti scaffolds for other cell types (i.e. human osteoblastic cell line hFOB 1.19) [15], meaning that the optimum microarchitecture could still be dependent on cell type or that there are other geometrical factors at play when the proliferation stage is commenced. On day 12 the behaviour of the scaffolds with the largest pore size and porosity (B4) rebounded and yielded the largest cell proliferation rate. Significant differences were found between A4 and B4 suggesting that larger porosities and large pore sizes play a critical role when cell proliferation is the dominant phase (Figure 6, Figure 7 and supplementary material).

Toluidine blue assay qualitative results were in agreement with the fluorescence results in that spots were not detected on scaffolds with pore ranges $212-300 \mu \mathrm{m}(\mathrm{A} 3)$ or $300-500 \mu \mathrm{m}$ (A4) for the lower porosity range, indicating a low level of proliferation, or on $212-300 \mu \mathrm{m}$ for the higher porosity scaffolds (B3) confirming the difficulty the cells experienced when spanning across that pore size. The blue hue on sample B4 confirmed the favourable conditions to cell proliferation for that microarchitecture. 
SEM images corroborated the results obtained via the Presto and the Toluidine blue assays. These images aided cell spreading analysis and also helped understand how attachment and growth progressed. Cells attached and proliferated on all samples but it can be observed that their strategy was different depending on the pore size range of the scaffold where they were seeded onto. The cells spread was denser on surfaces with smaller pore sizes (i.e. 45-212 $\mu \mathrm{m}$ ) (Figure 9d-e) and spanned across the gaps left by the pores (Figure 9f). The cells were flat and presented cellular micro-extensions that confirmed cellular spreading and cell-cell communication through membrane contact amongst them. The cells growing on scaffolds with pore sizes larger than $300 \mu \mathrm{m}$ grew into the cavities and these could be seen as heavily populated on day 12 of incubation (Figure $9 \mathrm{~g}$ and i). Cells growing on porous scaffolds $200-300 \mu \mathrm{m}$ also attached onto the surfaces, but the pores typically appeared not colonised as the cells had difficulty in bridging the gap across those pores (Figure 9h). This result is in agreement with other studies [41] which report sizes $<212 \mu \mathrm{m}$ are preferred for predominant cell attachment and $>300 \mu \mathrm{m}$ for cell proliferation and ingrowth.

\section{Conclusions}

An optimum balance between mechanical properties (stiffness and strength) and microarchitecture (porosity and pore size) must be achieved to ensure long-term successful implantation. Titanium porous scaffolds were manufactured in two ranges of porosities so their mechanical properties could mimic those of cortical and trabecular bone. The spaceholder volumetric content remained constant while the pore size ranges were varied. This allowed a study of the Young's modulus and compressive strength as a function of porosity and pore size. Power law correlations best fitted the results so they are good predictors of mechanical properties in the Ti sintered metal powder. Young's moduli fitted well the ranges of both cortical and trabecular bone while the compressive strengths were $84 \%$ higher than the ranges reported for those types of bones. The open porosity ranges fitted well with those of cortical bone ( $5-13.5 \%$ vs $5 \%$ ) but were lower for the trabecular ones (15-39\% vs $60 \%+$ ).

From a bioengineering viewpoint, the results from this study showed that scaffolds with the lowest pore range $(45-106 \mu \mathrm{m})$ presented the largest number of cells attached in the early days (day 1 and 3 ) indicating this microarchitecture was the best advised for the early stages of attachment. However, cell proliferation rate in this pore range is slower than that on other larger pore sizes. Pore range $>300 \mu \mathrm{m}$ exhibited the most favourable conditions for cell proliferation, surpassing those on the control samples. The viability of scaffolds with pore size $212-300 \mu \mathrm{m}$ was the poorest, indicating these scaffolds do not promote cell proliferation 
for osteosarcoma osteoblasts $143 \mathrm{~B}$ due to the distance the cells had to span. This was most apparent in the larger porosity scaffolds, which suggests the static growth of the cells was inhibited when exposed to that microarchitecture. These results confirm that microarchitecture plays a key role in both early and subsequent stages for the attachment and growth of in vivo cells on porosity controlled Ti scaffolds.

Acknowledgements:

FRAA was funded by the Cultural Bureau of the Royal Embassy of Saudi Arabia in London (no. JU55). MN was funded by an internal Wolfson School Visiting Scholarship for the duration of this study. The authors are grateful to Erasmus+ Traineeship (progetto I-REEF, PR-T3, no. 61/2016) for supporting MN during his training. Dr A Chandra and Ms P Holland helped with the work at the Centre for Biological Engineering, Loughborough.

\section{References:}

[1] S.L. Zhu, X.J. Yang, M.F. Chen, C.Y. Li, Z.D. Cui, Effect of porous NiTi alloy on bone formation: A comparative investigation with bulk NiTi alloy for 15 weeks in vivo, Materials Science and Engineering: C 28(8) (2008) 1271-1275.

[2] D.C. Wirtz, N. Schiffers, T. Pandorf, K. Radermacher, D. Weichert, R. Forst, Critical evaluation of known bone material properties to realize anisotropic FEsimulation of the proximal femur, Journal of Biomechanics 33(10) (2000) 1325-1330. [3] R. Dickenson, W. Hutton, Stott, The mechanical properties of bone in osteoporosis, Journal of Bone \& Joint Surgery, British Volume 63-B(2) (1981) 233238.

[4] A. Burstein, D. Reilly, M. Martens, Aging of bone tissue: mechanical properties, The Journal of Bone \&amp; Joint Surgery 58(1) (1976) 82-86.

[5] E.F. Morgan, T.M. Keaveny, Dependence of yield strain of human trabecular bone on anatomic site, Journal of Biomechanics 34(5) (2001) 569-577.

[6] P.K. Zysset, X. Edward Guo, C. Edward Hoffler, K.E. Moore, S.A. Goldstein, Elastic modulus and hardness of cortical and trabecular bone lamellae measured by nanoindentation in the human femur, Journal of Biomechanics 32(10) (1999) 10051012.

[7] E.F. Morgan, H.H. Bayraktar, T.M. Keaveny, Trabecular bone modulus-density relationships depend on anatomic site, Journal of Biomechanics 36(7) (2003) 897904.

[8] K. Choi, J.L. Kuhn, M.J. Ciarelli, S.A. Goldstein, The elastic moduli of human subchondral, trabecular, and cortical bone tissue and the size-dependency of cortical bone modulus, Journal of Biomechanics 23(11) (1990) 1103-1113.

[9] T.A. Albrektsson, C.J. Johansson, Osteoinduction, osteoconduction and osseointegration, European Spine Journal 10(0) (2001) S96-S101.

[10] D. Tadic, F. Beckmann, T. Donath, M. Epple, Comparison of different methods for the preparation of porous bone substitution materials and structural investigations by synchrotron $\mu$-computer tomography, Materialwissenschaft und Werkstofftechnik 35(4) (2004) 240-244.

[11] V. Karageorgiou, D. Kaplan, Porosity of 3D biomaterial scaffolds and osteogenesis, Biomaterials 26(27) (2005) 5474-5491. 
[12] K.H. Frosch, F. Barvencik, C.H. Lohmann, V. Viereck, H. Siggelkow, J. Breme, K. Dresing, K.M. Stürmer, Migration, Matrix Production and Lamellar Bone Formation of Human Osteoblast-Like Cells in Porous Titanium Implants, Cells Tissues Organs 170(4) (2002) 214-227.

[13] M. de Wild, S. Zimmermann, J. Rüegg, R. Schumacher, T. Fleischmann, C.

Ghayor, F.E. Weber, Influence of Microarchitecture on Osteoconduction and Mechanics of Porous Titanium Scaffolds Generated by Selective Laser Melting, 3D Printing and Additive Manufacturing 3(3) (2016) 142-151.

[14] W. Xue, B.V. Krishna, A. Bandyopadhyay, S. Bose, Processing and biocompatibility evaluation of laser processed porous titanium, Acta biomaterialia 3(6) (2007) 1007-1018.

[15] R. Stangl, B. Rinne, S. Kastl, C. Hendrich, The influence of pore geometry in cp Ti-implants-A cell culture investigation, Eur Cell Mater 2(2) (2001) 1-9.

[16] C.M. Murphy, M.G. Haugh, F.J. O'Brien, The effect of mean pore size on cell attachment, proliferation and migration in collagen-glycosaminoglycan scaffolds for bone tissue engineering, Biomaterials 31(3) (2010) 461-466.

[17] Y. Li, J. Xiong, P.D. Hodgson, C.e. Wen, Effects of structural property and surface modification of Ti6Ta4Sn scaffolds on the response of SaOS2 cells for bone tissue engineering, Journal of Alloys and Compounds 494(1-2) (2010) 323-329.

[18] G. Ryan, A. Pandit, D.P. Apatsidis, Fabrication methods of porous metals for use in orthopaedic applications, Biomaterials 27(13) (2006) 2651-2670.

[19] A. Nouri, P.D. Hodgson, C.E. Wen, Effect of process control agent on the porous structure and mechanical properties of a biomedical $\mathrm{Ti}-\mathrm{Sn}-\mathrm{Nb}$ alloy produced by powder metallurgy, Acta Biomaterialia 6(4) (2010) 1630-1639.

[20] J. Xiong, Y. Li, X. Wang, P. Hodgson, C.e. Wen, Mechanical properties and bioactive surface modification via alkali-heat treatment of a porous $\mathrm{Ti}-18 \mathrm{Nb}-4 \mathrm{Sn}$ alloy for biomedical applications, Acta Biomaterialia 4(6) (2008) 1963-1968.

[21] C. Torres-Sanchez, J.R. Corney, Morphological and biological characterization of density engineered foams fabricated by ultrasonic sonication, Journal of Materials Science 46(2) (2011) 490-499.

[22] D.S. Li, Y.P. Zhang, X. Ma, X.P. Zhang, Space-holder engineered porous NiTi shape memory alloys with improved pore characteristics and mechanical properties, Journal of Alloys and Compounds 474(1-2) (2009) L1-L5.

[23] M. Köhl, T. Habijan, M. Bram, H.P. Buchkremer, D. Stöver, M. Köller, Powder Metallurgical Near-Net-Shape Fabrication of Porous NiTi Shape Memory Alloys for Use as Long-Term Implants by the Combination of the Metal Injection Molding Process with the Space-Holder Technique, Advanced Engineering Materials 11(12) (2009) 959-968.

[24] A. Bansiddhi, D.C. Dunand, Shape-memory NiTi foams produced by solid-state replication with $\mathrm{NaF}$, Intermetallics 15(12) (2007) 1612-1622.

[25] P. Cools, N. De Geyter, E. Vanderleyden, P. Dubruel, R. Morent, Surface Analysis of Titanium Cleaning and Activation Processes: Non-thermal Plasma Versus Other Techniques, Plasma Chemistry and Plasma Processing 34(4) (2014) 917-932.

[26] D.P.H. Hasselman, R.M. Fulrath, Effect of Small Fraction of Spherical Porosity on Elastic Moduli of Glass, Journal of the American Ceramic Society 47(1) (1964)

52-53.

[27] R.B. Martin, R.R. Haynes, Confirmation of Theoretical Relation Between Stiffness and Porosity in Ceramics, Journal of the American Ceramic Society 54(8) (1971) 410-411. 
[28] M.Y. Balshin, Relation of mechanical properties of powder metals and their porosity and the ultimate properties of porous metal-ceramic materials, Dokl Akad Nauk SSSR, 1949, pp. 831-834.

[29] A.S. Wagh, R.B. Poeppel, J.P. Singh, Open pore description of mechanical properties of ceramics, Journal of Materials Science 26(14) (1991) 3862-3868. [30] A.K. Maitra, K.K. Phani, Ultrasonic evaluation of elastic parameters of sintered powder compacts, Journal of Materials Science 29(17) (1994) 4415-4419.

[31] L.J. Gibson, M.F. Ashby, Cellular solids: structure and properties, 2nd ed., Cambridge University Press 1997.

[32] F.P. Knudsen, Effect of Porosity on Young's Modulus of Alumina, Journal of the American Ceramic Society 45(2) (1962) 94-95.

[33] W. Duckworth, Discussion of Ryshkewitch Paper by Winston Duckworth, Journal of the American Ceramic Society 36(2) (1953) 68-68.

[34] D.S. Metsger, M.R. Rieger, D.W. Foreman, Mechanical properties of sintered hydroxyapatite and tricalcium phosphate ceramic, Journal of Materials Science: Materials in Medicine 10(1) (1999) 9-17.

[35] D.P. Mondal, N. Ramakrishnan, K.S. Suresh, S. Das, On the moduli of closedcell aluminum foam, Scripta Materialia 57(10) (2007) 929-932.

[36] C.E. Wen, Y. Yamada, K. Shimojima, Y. Chino, T. Asahina, M. Mabuchi, Processing and mechanical properties of autogenous titanium implant materials, Journal of Materials Science: Materials in Medicine 13(4) (2002) 397-401.

[37] M. Bram, H. Schiefer, D. Bogdanski, M. Köller, H.P. Buchkremer, D. Stöver, Implant surgery: How bone bonds to PM titanium, Metal Powder Report 61(2) (2006) 26-31.

[38] B. Wysocki, J. Idaszek, K. Szlązak, K. Strzelczyk, T. Brynk, K. Kurzydłowski, W. Święszkowski, Post Processing and Biological Evaluation of the Titanium Scaffolds for Bone Tissue Engineering, Materials 9(3) (2016) 197.

[39] Y. Torres, J.A. Rodríguez, S. Arias, M. Echeverry, S. Robledo, V. Amigo, J.J. Pavón, Processing, characterization and biological testing of porous titanium obtained by space-holder technique, Journal of Materials Science 47(18) (2012) 6565-6576.

[40] C.E. Wen, M. Mabuchi, Y. Yamada, K. Shimojima, Y. Chino, T. Asahina, Processing of biocompatible porous Ti and Mg, Scripta Materialia 45(10) (2001) 1147-1153.

[41] B. Chang, W. Song, T. Han, J. Yan, F. Li, L. Zhao, H. Kou, Y. Zhang, Influence of pore size of porous titanium fabricated by vacuum diffusion bonding of titanium meshes on cell penetration and bone ingrowth, Acta Biomaterialia 33 (2016) 311-321. 
Supplementary material
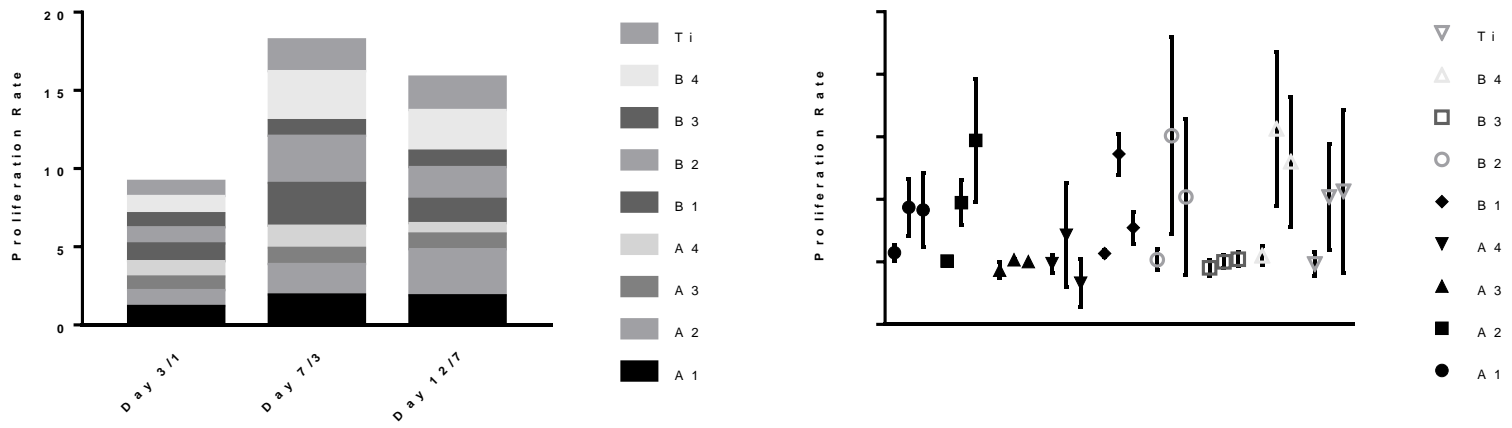

Figure S1: (a) Proliferation rates of 143B osteoblasts on titanium porous (A,B 1-4) and nonporous (Ti) normalised to the previous timepoint of culture $\left(\mathrm{i}_{\mathrm{n}} / \mathrm{i}_{\mathrm{n}-1}, \mathrm{n}=3,7,12\right)$; (b) Proliferation rates showing error propagation values 